\title{
Resenha: \\ O banqueiro anarquista, de Fernando Pessoa ${ }^{1}$
}

Adriano Moraes Migliavacca ${ }^{2}$

Há sempre algo de insólito em se visitar a produção de um conhecido escritor em um gênero que sempre ocupou um local de menor destaque em sua obra ou, pelo menos, um no qual ele é menos célebre entre nós. É comum, nesse caso, ficarmos buscando aqui e ali algo da dicção, do estilo, dos temas ou imagens que caracterizam sua obra naquele gênero em que ele nos é familiar. Em muitas dessas situações, no entanto, o que ocorre é que acabamos tendo contato com dimensões do estilo e da personalidade desse escritor que sempre nos escaparam.

Quando folhamos a obra em prosa de Fernando Pessoa, nos deparamos com uma variedade de temas e assuntos que chama a atenção pela amplitude de interesses desse paradigmático poeta modernista. Além das já esperadas páginas dedicadas à investigação estética e à crítica literária, vemos lá discussões sobre filosofia, sistemas de pensamento religiosos, política e, o que talvez surpreenda um pouco mais, sobre teoria e prática de comércio. Esse interesse em política e teoria econômica se reflete naquela que é talvez sua incursão mais conhecida no âmbito da ficção curta: o conto "O banqueiro anarquista", publicado separadamente em uma bela edição da Editora José Olympio, pertencente à série Sabor Literário, contando ainda com uma apresentação do professor Francisco Maciel Silveira.

O paradoxo do título, ou, como precisa o professor Maciel Silveira, oximoro, nos indica de entrada a ironia de que se carregam o estilo e o teor do conto. Dois amigos jantam juntos, um, o narrador; outro, nos informa este, um notório e bem-sucedido banqueiro. Tendo terminado a refeição e o assunto, o narrador pergunta ao seu amigo sobre rumores que o descrevem em tempos antigos como anarquista. "Fui, não: fui e sou. Não mudei a esse respeito. Sou anarquista", lhe responde o banqueiro. A partir de então, passa o leitor a acompanhar o narrador anônimo em sua crescente curiosidade com relação a esse anarquismo que o próprio banqueiro nega ter qualquer sentido diferente do usual $\mathrm{E}$ mais: diz-se, ele sim, um anarquista de verdade, na teoria e na prática, sem que uma se desalinhe da outra; os outros, "esses tipos das bombas e dos sindicatos", como nos diz o narrador, é que o são com menos consistência.

O que se deslinda a seguir é um longo diálogo cujo modelo, aponta o professor Maciel Silva, parece mesmo ser o diálogo platônico, no qual acompanhamos uma breve biografia ideológica do banqueiro anarquista. Era, ele nos faz saber, de origem humilde e por volta dos 20 ou 21 anos conheceu e decidiu adotar a doutrina anarquista, tendo se aproximado de um grupo de pessoas que partilhavam das mesmas crenças políticas que ele. Ao longo de sua vida como anarquista, verificou a corrupção de grande parte dos ideais entre seus companheiros. Viu como no bojo do grupo se instaurou uma tirania e, desiludido, afastou-se, tendo se tornado subsequentemente o banqueiro bem-sucedido e rico que era.

Até então, compartilhamos com o narrador a impressão de termos diante de nós uma típica história de desilusão ideológica; de alguém que, tendo se decidido desde cedo a combater o sistema burguês, acaba por chegar à conclusão da inutilidade de sua luta, deci-

1 Rio de Janeiro: Editora José Olympio. Coleção Sabor Literário. 2006.

2 Doutorando em Letras UFRGS. 
dindo compactuar com esse mesmo sistema e desfrutar de todos os seus luxos e requintes. Assim se apresenta, externamente, a trajetória do banqueiro anarquista. A trajetória interna que esse personagem narra, no entanto, aponta para outro caminho.

O cerne da narrativa autobiográfica do banqueiro não são os eventos de sua história, mas sim seu desenvolvimento intelectual. Mais interessante: o que ele nos apresenta não é uma concepção anarquista em evolução, pois a teoria anarquista, como ele próprio diz, continua a mesma desde o início de seu engajamento até o tempo em que transcorre a história. O fio condutor de sua biografia é a evolução de sua concepção da prática anarquista e sua concretização em sua própria existência pessoal, chegando ao momento em que a vida de banqueiro rico não só não se encontra em contradição com seus ideais políticos, mas se mostra a única forma de vivê-los efetivamente.

A luta anarquista, nos diz ele, busca a liberdade de todos e se volta contra as desigualdades sociais, que o banqueiro opõe às desigualdades naturais, estas incontornáveis. Aquelas, nos informa ele, resultam da influência deletéria das ficções sociais - dimensões da identidade, tais como pátria, religião, status familiar e profissão, que não são naturais, mas criadas pelo homem e que, por isso mesmo, o oprimem. Tais ficções sociais só podem ser destruídas por uma revolução social, algo que o próprio personagem considera, no momento, impraticável. É necessário buscar meios de se preparar a sociedade para essa revolução social enquanto ela não pode ser efetuada. O que ele vê entre seus companheiros ideológicos é a busca por uma superação das ficções sociais por meio de outras ficções sociais - o auxílio, o altruísmo - pelas quais o homem simplesmente afirma sua superioridade sobre outros e cria mais tirania, aliás, uma nova tirania. A forma de realmente prosseguir com a luta seria, portanto, começar uma guerra solitária contra as ficções sociais, vencê-las sozinho. A primeira e mais importante, segundo ele, é o dinheiro, e o modo de vencê-lo, de anular sua influência, seria adquiri-lo em tanta quantidade que não mais se lhe sentisse a influência. Foi assim que chegou a banqueiro. Não podendo libertar a humanidade inteira de uma vez, ele começou esse árduo trabalho libertando uma pessoa: ele mesmo.

$\mathrm{O}$ que chama a atenção em $\mathrm{O}$ banqueiro anarquista é como, a partir de uma doutrina a princípio revolucionária e coletivista, o personagem vem a justificar uma vida conservadora e individualista, assim podemos dizer, pois conservadorismo e individualismo assombram algumas das justificativas dadas pelo banqueiro. $\mathrm{O}$ narrador, que se mostra em grande parte mais ativo que muitos dos interlocutores de Sócrates nos diálogos platônicos, aponta para o fato de ele ter, com sua prática, criado mais tirania, pelo menos no campo financeiro. A isso, nosso banqueiro imediatamente responde que o que ele engendrou é um pouco mais de uma tirania que já havia, quando o problema é criar-se uma nova tirania, como o fizeram seus antigos companheiros, um postulado consideravelmente conservador ou conformista. Da mesma forma, em outro momento, o narrador comenta que sua capacidade de libertar-se a si mesmo, algo que o banqueiro diz que outros também deveriam fazer, resultou de uma inteligência maior, que o permitiu chegar aonde chegou. Inabalado, o banqueiro lembra que essa capacidade se origina não em uma ficção social, mas em uma desigualdade natural. Muitos de seus antigos companheiros teriam nascido para escravos e, para estes, não há maior tirania que a liberdade. Nesse ponto, nosso personagem desemboca não apenas no individualismo, mas em um verdadeiro aristocratismo natural.

A apresentação do professor Francisco Maciel Silveira, que reproduz elegantemente o estilo dialógico do conto, faz bem em aproximar o desenvolvimento do conto com algumas das observações políticas do próprio Fernando Pessoa. O poeta, nos diz o professor, 
desprezava democratismo, socialismo e anarquismo como "divinizações da mentira" que se esquecem da humanidade concreta; humanidade, indivíduo e a nação constituíam as realidades concretas para Pessoa, o que o fazia adotar para si o liberalismo individualista. Família, religião, classe, estado e civilização eram ficções sem valor real, no que Pessoa parece aproximar-se do anarquismo. Nesse ponto, nos diz o professor, é que Pessoa se assemelha um pouco a seu personagem, pois, rebelando-se contra as tais ficções, e exercendo, portanto, o anarquismo, Pessoa precisava negar também o caráter partidário do anarquismo e que fazia dele a mentira que o liberal Pessoa dizia que ele é.

A convergência inclusive estilística entre o estudo crítico do professor Maciel Silva e o conto de Pessoa fazem dessa edição da José Olympio um item valioso. Nela não só podemos nos aproximar do Pessoa proseador, do Pessoa contista, mas também um pouco do Pessoa pensador político - duas facetas interessantes dessa figura literária que teve tantas. 